Asian J. Med. Biol. Res. 2019, 5 (3), 231-236; doi: 10.3329/ajmbr.v5i3.43593

\author{
Asian Journal of \\ Medical and Biological Research \\ ISSN 2411-4472 (Print) 2412-5571 (Online) \\ www.ebupress.com/journal/ajmbr
}

Article

\title{
Cytotoxic potential of camel whey and milk on cervix cancer (HeLa) cell line
}

\author{
Lubna A. Abdallah*, Ashraf M. Sawafta, Sanad A. Ben Ali and Hasan A. Baradia \\ Department of Biology and Biotechnology, Faculty of Science, An-Najah National University, Nablus, Palestine
}

*Corresponding author: Lubna Abdallah, Department of Biology and Biotechnology, Faculty of Science, AnNajah National University, Nablus, Palestine. Telephone: +970 (9) 2345113 Ext (2365); E-mail: alubna@najah.edu; Fax: +970 (9) 2345982

Received: 29 August 2019/Accepted: 26 September 2019/ Published: 30 September 2019

\begin{abstract}
Camel milk is an important nutritional source that historically been used in the treatment of cancer. Therefore, the main aim of the present study is to determine the in vitro anticancer effect of both camel milk and whey against cervix cancer (HeLa) cells. To perform that, skimmed milk as well as whey immunoglobulins concentrate samples were prepared at different concentrations $(0,1,2.5,5,7.5$ and $10 \mathrm{mg} / \mathrm{ml})$. Then, the in vitro effect of the prepared concentrations on HeLa cells morphology and growth was investigated by tissue culture technique. Moreover, the anticancer activity of camel milk and whey against HeLa cells was estimated by the 3-[4, 5dimethylthiazole-2-yl]-2, 5-diphenyltetrazolium bromide (MTT) assay. The obtained results displayed that both camel milk and whey reduced the viability of HeLa cells specially at 7.5 and $10 \mathrm{mg} / \mathrm{ml}$. In addition, the viability of treated HeLa cells reduced after addition of both camel milk and whey to approximately $15 \%$ in a concentration dependent manner. In conclusion, this study showed the in vitro cytotoxic effect of camel milk and whey as they inhibited the growth of HeLa cells.
\end{abstract}

Keywords: camel; whey and milk; cytotoxic potential; cervix cancer (HeLa) cell line

\section{Introduction}

Cancer management in humans is a major challenge for modern medicine as there are no available medications that can selectively kill cancer cells without any effect on other normal living ones (Coufal et al., 2007; Kontou et al., 2011). The standard available therapies depend on surgery, chemotherapy, radiotherapy, hormone therapy, and immunotherapy (Khorshid et al., 2010). The primary method for cancer treatment among the previous methods is chemotherapy which has long lasting side effects (Rood et al., 2004). The drawbacks of some methods that are used for cancer treatment underline the necessity for the development of alternative ones with minimal side effects. One of these alternatives are natural products which known to be one of the important sources of therapeutically effective substances (Alebie et al., 2017). A novel chemoprevention that depend on dietary constituents is camel milk. It is a beneficial source of many useful organic substances that have a promising therapeutic values (Alghamdi and Khorshid, 2012).

Camel milk is an important nutritional source as it has many properties that make it very useful choice for the treatment of diverse diseases in some parts of the world (Attia et al., 2001). In addition to its high content of minerals and vitamins as well as high concentrations of insulin, camel milk has low content of cholesterol and sugars (Farah et al., 1992). Moreover, studies demonstrated that camel milk contains great concentrations of protective proteins, including lysozyme, lactoferrin, lactoperoxidase, peptidoglycan recognition protein (PGRP) enzyme, immunoglobulin G, and secretory immunoglobulin A (El Agamy et al., 1992). Furthermore, the protective proteins in camel milk may have a possible role for enhancing the immune defense mechanism (Yagil, 1982). Among these proteins, whey proteins that play an important role as an anti-tumor and anticarcinogenic agent (Zarogoulidis., 2015). Whey proteins protect the immune system by acting as an immunodulatory factors through which they activate different immune cell functions (Badr et al., 2017). The unique properties of camel IgG antibodies which lack light chains enable them to posses different biological 
activities (Harmsen and De Haard, 2007). Traditionally, camel milk has cured and treated numerous cases of cancer. The anticancer potential of camel milk was referred to its cytotoxic effect, anti-apoptotic effect and antiproliferative effect (Alebie et al., 2017). However, few studies have been published in literature regarding the medicinal properties of camel milk and whey against cancer (Almahdy et al., 2011; Korashy et al., 2012; Habib et al., 2013; El Miniawy et al., 2014; Vladimir et al., 2017). According to that, this study was investigated to determine the ability of camel milk and whey to inhibit the growth of HeLa cells in vitro.

\section{Materials and Methods}

\subsection{Milk collection and whey immunoglobulins preparation}

Veterinary specialist collected milk samples from one female camel (Jenin, West Bank). For whey preparation, the casein was precipitated from the pooled skimmed milk samples by milk renneting with commercially available rennin to obtain good crude contraction (Brussow et al. 1987). The coagulated milk was heated to $56^{\circ} \mathrm{C}$ for $10 \mathrm{~min}$. Casein separation from lacto serum was carried out by filtration. For final clarification, the lacto serum was again centrifuged for $30 \mathrm{~min}$ at $10,000 \mathrm{rpm}$ at $4^{\circ} \mathrm{C}$. The supernatant was filtered using a millipore filter $(0.45 \mu \mathrm{m})$, then the filtered supernatant was lyophilized to get powder of whey immunoglobulins pool. Total protein content of camel whey sample was determined by Biuret method (Gornall et al., 1949). For milk preparation other skimmed milk sample was directly freeze-dried to produce milk powder.

\subsection{Identification of camel whey proteins using sodium dodecyl sulfate polyacrylamide gel electrophoresis (SDS-PAGE)}

Components of whey immunoglobulin concentrate and milk samples were fractionated by SDS-PAGE. This was performed in the discontinuous buffer system using $12 \%$ acrylamide-bisacrylamide separating gel (pH 8.8) and $4 \%$ acrylamide-bisacrylamide stacking gel (pH 6.8). Samples were mixed in 3:1 ratio with sample buffer (pH 6.8). For band size determination, molecular weight protein standards were used. The gel was stained with coomassie brilliant blue R-250 and destained by $30 \%$ methanol until clear bands were seen.

\subsection{Anti-cancer activity}

\subsubsection{In vitro morphological study}

The human cervical cancer cell lines (HeLa cells) were obtained from the American Type Culture Collection [ATCC], Manassas, VA, USA. For screening experiment, the cells were seeded into 12 -well plates in $900 \mu 1$ of RPMI medium (Biological Industries, USA) containing 5\% FBS, at plating density of $\left(2 * 10^{4}\right.$ cells/well). Whey and milk samples were solubilized in $0.2 \mathrm{M}$ phosphate buffer $(\mathrm{pH}, 7)$, then $100 \mu \mathrm{l}$ of various concentrations $(1$, $2.5,5,7.5$ and $10 \mathrm{mg} / \mathrm{ml}$ ) was added in duplicates to the prepared 12 -well plates and incubated at $37^{\circ} \mathrm{C}, 5 \%$ $\mathrm{CO} 2,95 \%$ air and $100 \%$ relative humidity for $24 \mathrm{~h}$. To observe the morphological changes of the cells an inverted microscope was used (Labomed, USA).

\subsubsection{MTT assay}

The anticancer effect of the camel milk and whey samples against HeLa cells was estimated by the 3-[4, 5dimethylthiazole-2-yl]-2, 5-diphenyltetrazolium bromide (MTT) assay using (cell growth determination kit MTT based, Sigma). Cells $\left(2 * 10^{4}\right.$ cells/well) were incubated with various concentrations of the compounds $(0$, $1,2.5,5,7.5 \mathrm{mg} / \mathrm{ml}$ ) at $37^{\circ} \mathrm{C} 5 \% \mathrm{CO} 2,95 \%$ air and $100 \%$ relative humidity for $24 \mathrm{~h}$ in a FBS-free medium. Aseptically MTT solution was added in an amount equal to $10 \%$ of the culture volume. Then cultures were returned to incubator and incubated for 4 hours. After the incubation period, the resulting MTT formazan crystals were dissolved by the addition of MTT solvent in an amount equal to the original culture volume. The addition of MTT solvent was performed after the removal and disposal of the culture fluid as HeLa cells were still attached to the culture surface. The absorbance at $570 \mathrm{~nm}$ was measured using micro plate reader (Labtech, UK). The relative cell viability was determined by the amount of MTT converted to the insoluble formazan salt. The data are expressed as the mean percentage of viable cells as compared to the respective control.

\section{Results}

\subsection{Identification of camel whey and milk proteins}

Sodium dodecyl sulfate polyacrylamide gel electrophoresis (SDS-PAGE) was done to determine the protein contents of camel whey and milk samples. The obtained results showed that whey sample lack casein, and contain high concentrations of IgG immunoglobulins in addition to moderate concentration of albumin and very low concentration of lactoferrin (Figure 1). 
3.2. In vitro morphological study

Results showed that both camel milk and whey reduced the viability of HeLa cells specially at $7.5 \mathrm{and} 10 \mathrm{mg} / \mathrm{ml}$ (Figures 2 and 3).

\subsection{MTT Results}

Viability of HeLa cells that treated with camel milk was reduced to $12.1-15.1 \%$ within in studied concentrations range (Figure 4). The same observation was noticed after whey treatment as the viability of HeLa cells reached 13-15.4\% (Figure 5). Cell growth was decreased with the increasing concentration of both camel milk and whey.

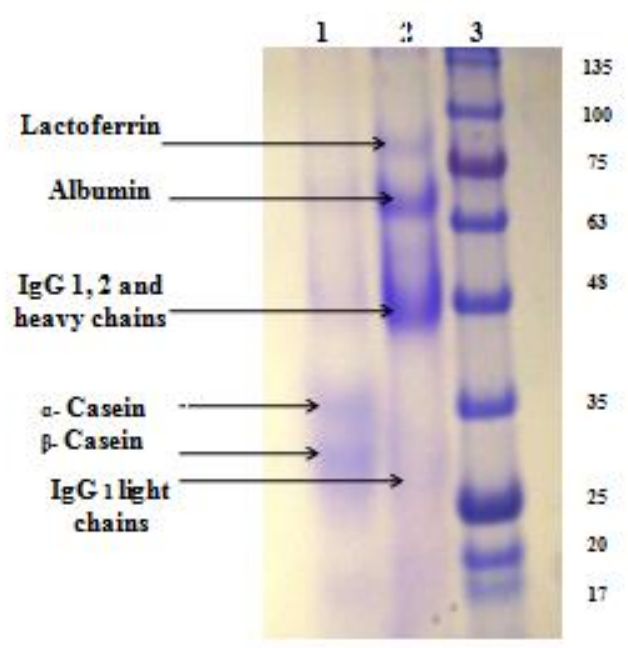

Figure 1. The SDS-PAGE pattern of camel milk (1) and whey (2), in addition to molecular weight standards (3).

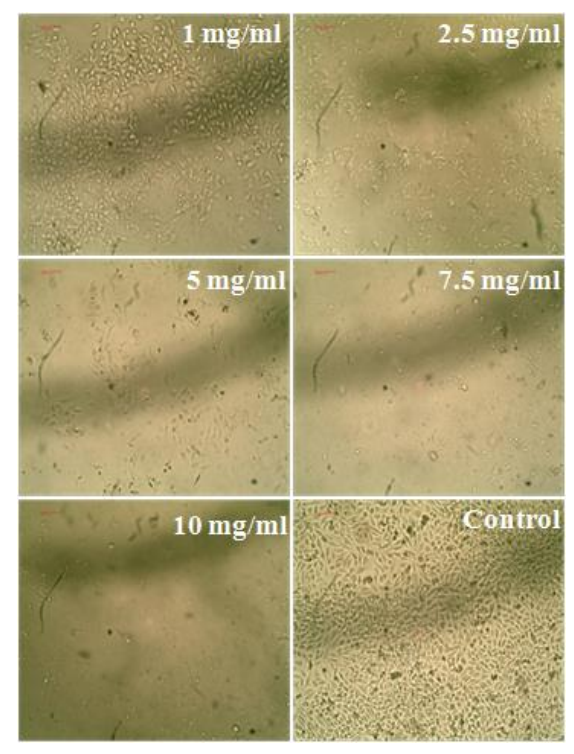

Figure 2. In vitro effect of camel milk on HeLa cells at different concentrations $(\mathrm{mg} / \mathrm{ml})$.

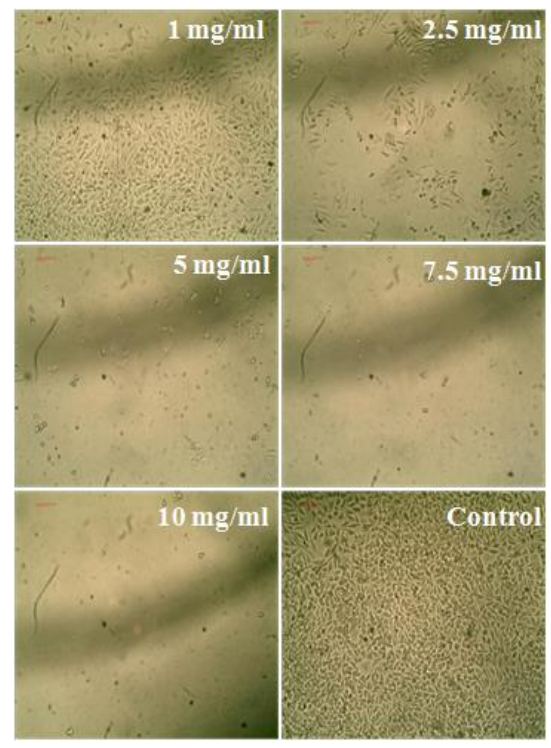

Figure 3. In vitro effect of camel whey on HeLa cells at different concentrations $(\mathrm{mg} / \mathrm{ml})$. 


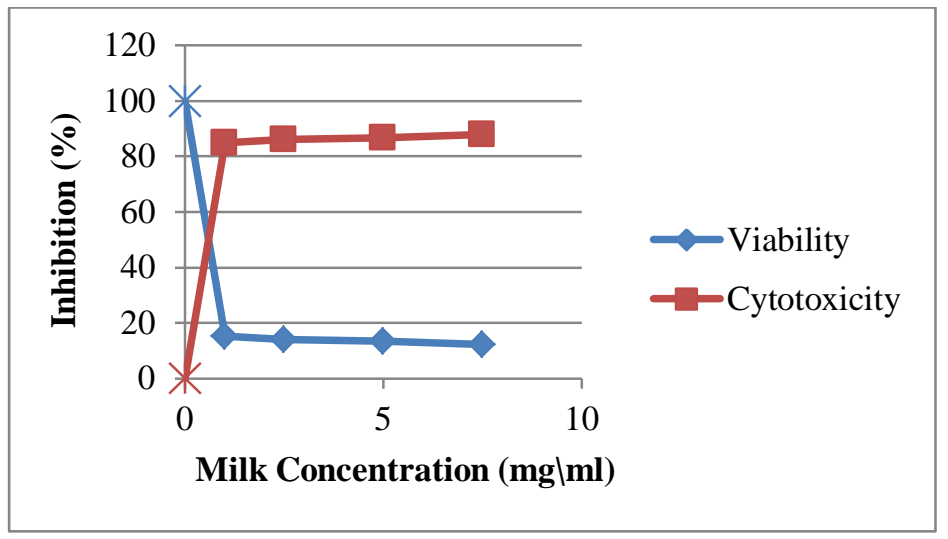

Figure 4. Effect of camel milk on the viability of HeLa cells by MTT assay.

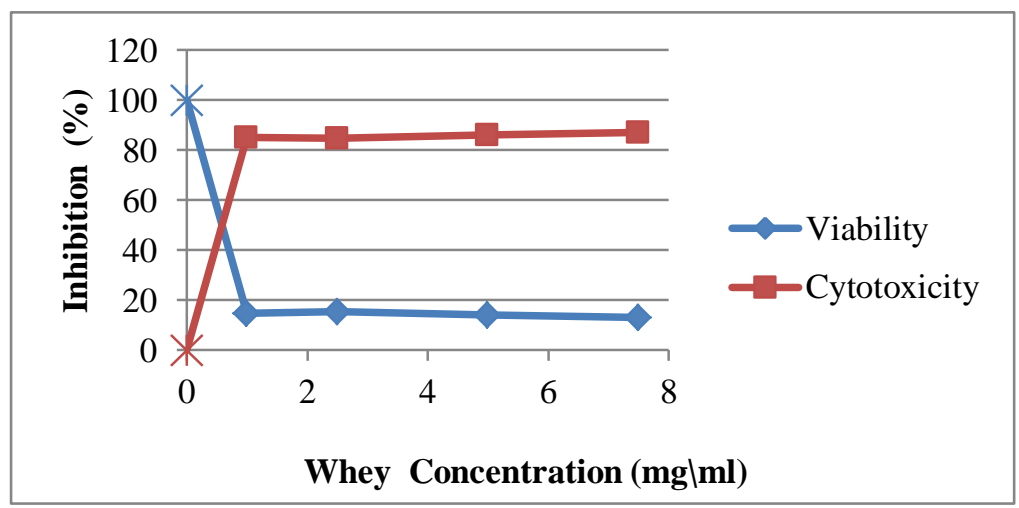

Figure 5. Effect of camel whey on the viability of HeLa cells by MTT assay.

\section{Discussion}

Chemoprevention by dietary constituents has a valuable role in the control of diverse diseases including cancer (Kontou et al., 2011). Camel milk is an example for an excellent source of these constituents that exhibit different biological activities (Yagil et al., 1982). In the present study camel milk and its whey proteins emerged as a powerful anticancer agents that reduced the in vitro growth of Hela cells. According to the obtained results, they showed a toxic effect on the studied cells that approximately reached $85 \%$. Apparently, camel milk is one of the natural products that has cytotoxic potential against cancer cells like murine hepatoma hepa 1c1c7 cells (Korashy et al., 2012). In the running study, the cytoxicity of camel milk and whey could be referred to the presence of casein, lactoferrin and immunoglobulins (Konuspayeva et al., 2007). It was recorded that camel milk increased the expression of chemo-protective genes which in turn increased the levels of several antioxidant enzymes. These enzymes prevent the formation of highly reactive oxygen species and so protect DNA and cell damage (Habib et al., 2013). Other study showed that casein and its product formed during pepsin hydrolysis had the ability to protect mammalian cells against certain genotoxic compounds (Van Boekel et al., 1993). Moreover, lactoferrin, the other component of camel milk exerts antitumor activity due to the immuneinducing and immunomodulatory properties (Al-Majali et al., 2007).

On the other hand, other studies indicated the ability of camel milk to induce apoptosis in various cancer cell lines. According to these studies, the apoptotic effect was on account of the activation of both extrinsic and intrinsic pathways. In this aspect, the induction of apoptosis occurred by several ways like enhancement of reactive oxygen species (ROS) production, activation of caspase-3 expression and induction of receptormediated apoptosis (Sidgi Hasson et al., 2015). Almahdy and his colleagues found that camel $\alpha$-lactalbumin initiated apoptosis in the examined HepG2 and HeLa cells. Additionally, a complex from camel milk albumin and oleic acid displayed a pronounced antitumor activity through the induction of apoptosis in a variety of tumor cells (El-Fakharany et al., 2018). However, the exact potency of camel milk in apoptotic activation is not well recognized (Almahdy et al., 2011).

Otherwise, camel milk caused a powerful anti-proliferative effect on various cancer cell lines. This antiproliferative effect is mostly due to the apoptotic and oxidative stress-mediated mechanisms (Habib et al., 2013, 
Korashy et al., 2012, Sidgi Hasson et al., 2015). In this regards, lactoferrin inhibited cancer cells proliferation through various mechanisms. One possible mechanism is the activation of cell signaling pathways that lead to cell apoptosis (Fujita et al., 2004). Other possibility is that lactoferrin can function as a transcription factor (Habib et al., 2013). Moreover, lactoferrin affect cell cycle by arresting the treated cells at the G1 phase and thus down-regulate their proliferation (Damiens et al., 1997).

Besides the previous studied milk proteins, camel antibodies are also have paid attention to scientists in cancer research. The hallmark of camel milk is that it contains a unique immunoglobulin type called the heavy chain antibodies along with nanobody which is also called the variable domain of the heavy chain antibody (VHH) (Evers et al., 2008). Those molecules are devoid of the light chains that normally present in conventional antibodies. The small size of heavy chain antibodies offer them the ability to penetrate different tissues that cannot be reached by other antibodies (Cortez et al., 2002). In spite of the high sequence homology between camel heavy chain antibodies and human ones, camel antibodies are less hydrophilic. In addition to that, camel VHH domains are non-immunogenic and specifically target solid and metastatic tumors (Muyldermans et al., 1994). Moreover, these antibodies have the ability to recognize epitopes which are less antigenic for conventional ones (Lauwereys et al., 1998). All the mentioned features allow camel antibodies to overcome the stickiness problems of conventional antibody domains as well as to exhibit a rapid pharmacokinetic clearance (Cortez-Retamozo et al., 2002). In overall, heavy chain antibodies that are naturally found in camel milk could be a very useful tools for cancer targeting, diagnosis and therapy.

\section{Conclusions}

In conclusion, this study showed the cytotoxic potential of both camel milk and whey as they inhibited the growth of HeLa cells in vitro. Nevertheless, the milk and whey components that are responsible for such anticancer activity are not determined in the running research. So there is a need for further studies to figure out the bioactive compounds in camel milk and whey and their exact mechanism of action against HeLa cells.

\section{Acknowledgements}

The authors are grateful to Biology and Biotechnology Department at An-Najah National University for allowing them to access their facilities.

\section{Conflict of interest}

None to declare.

\section{References}

Alebie G, S Yohannes and A Worku, 2017. Therapeutic applications of camel's milk and urine against cancer: current development efforts and future perspectives. J. Cancer. Sci. Ther., 9: 468-478.

Alghamdi Z and F Khorshid, 2012. Cytotoxicity of the urine of different camel breeds on the proliferation of lung cancer cells, A549. J. Nat. Sci. Re., 2: 9-13.

Almahdy O, EM EL-Fakharany, E EL-Dabaa, TB Ng and EM Redwan, 2011. Examination of the Activity of Camel Milk Casein against Hepatitis C Virus (Genotype-4a) and Its Apoptotic Potential in Hepatoma and HeLa Cell Lines. Hepat. Mon., 11: 724-730.

Al-Majali AM, Z Bani Ismail, Y Al-Hami and AY Nour, 2007. Lactoferrin concentration in milk from camel (Camelus dromedarius) with and without subclinical mastitis. Int. J. Appl. Res. Vet. Med., 5: 120-124.

Attia H, N Kherouatou and A Dhouib, 2001. Dromedary milk lactic acid fermentation: microbiological and rheological characteristics. J. Ind. Microbiol. Biotechnol., 26: 263-270.

Badr G, N Ramadan, L Sayed, B Badr, H Omar and Z Selamoglu, 2017. Camel whey protein as a new dietary approach to the management of free radicals and for the treatment of different health disorders. J. Basic. Med. Sci., 20: 338-349.

Brussow H, H Hilpert, I Walther, J SIidoti, C Mietens and P Bachmann, 1987. Bovine milk immunoglobulins for passive immunity to infantile rotavirus gastroenteritis. J. Clin. Microbiol., 25: 982-986.

Cortez-Retamozo V, M Lauwereys, G Hassanzadeh, M Gobert, K Conrath, S Muyldermans, P De Baetselier and $\mathrm{H}$ Revets, 2002. Efficient tumor targeting by single-domain antibody fragments of camels. Int. J. Cancer., 98: 456-462.

Coufal M, MM Maxwell, DE Russel, AM Amore, SM Altmann, ZR Hollingsworth, AB Young, DE Housman and AG Kazantsev, 2007. Discovery of novel small-molecule targeting selective clearance of mutant hunting in fragments. J. Biomol. Screen., 12: 351-360. 
Damiens E, IE Yazidi, J Mazurier, I Duthille and G Spik, 1997, Lactoferrin inhibits G1 cyclin-dependent kinases during growth arrest of human breast carcinoma cells. J. Cell. Biochem., 74: 486-498.

El Agamy EI, R Ruppanner, A Ismail, CP Champagne and R Assaf, 1992. Antibacterial and antiviral activity of camel milk protective proteins. J. Dairy. Res., 59: 169-175.

El-Fakharany EM, MM Abu-Serie, EA Litus, EP Sergei, AP Eugene, NU Viadimir and MR Elrashdy, 2018. The use of human, bovine, and camel milk albumins in anticancer complexes with oleic acid. Protein. J., 37: 203-215.

El Miniawy FMH, AA Kawkab, MA Tony, SA Mansour and MMS Khattab, 2014. Camel milk inhibits murine hepatic carcinogenesis, initiated by diethylnitrosamine and promoted by phenobarbitone. Int. J. Vet. Sci. Med., 2: 136-141.

Evers JM, RG Haverkamp, SE Holroyd, GB Jameson, DDS Mackenzie and OJ McCarthy, 2008. Heterogeneity of milk fat globule membrane structure and composition as observed using fluorescence microscopy techniques. Int. Dairy. J., 18: 1081-1089.

Farah Z, R Rettenmaier and D Atkins, 1992. Vitamin content of camel milk. Int. J. Vitam. Nutr. Res., 62: 30-33.

Fujita K, E Matsuda, K Sekine, M Iigo and H Tsuda, 2004. Lactoferrin enhances Fas expression and apoptosis in the colon mucosa of azoxymethane-treated rat. Carcinogenesis, 25: 1961-1966.

Gornall AG, CJ Bardawill and MM David, 1949. Determination of serum proteins by means of the biuret reaction. J. Biol. Chem., 177: 751-766.

Habib HM, WH Ibrahim, R Schneider-Stock and HM Hassan, 2013. Camel milk lactoferrin reduces the proliferation of colorectal cancer cells and exerts antioxidant and DNA damage inhibitory activities. Food. Chem., 141: 148-152.

Harmsen MM and HJ De Haard, 2007. Properties, production, and applications of camelid single-domain antibody fragments. Appl. Microbiol. Biotechnol., 77: 13-22.

Khorshid FA, H Shazly, A Al-Jefery and AA Osman, 2010. Dose escalation phase I study in healthy volunteers to evaluate the safety of a natural product PM701. Pharmacol. Toxicol., 5: 91-97.

Kontou N, T Psaltopoulou, D Panagiotakos, MA Dimopoulos and A Linos, 2011. The mediterranean diet in cancer prevention: a review. J. Med. Food., 14: 1065-1078.

Konuspayeva G, B Faye, G Loiseau and D Levieux, 2007. Lactoferrin and immunoglobulin contents in camel's milk (Camelus bactrianus, Campus dromedarius, and Hybrids) from Kazakhstan. J. Dairy. Sci., 90: 38-46.

Korashy HM, ZH Maayah, AR Abd-Allah, AOS El-Kadi and AA Alhaider, 2012. Camel milk triggers apoptotic signaling pathways in human hepatoma HepG2 and breast cancer MCF7 cell lines through transcriptional mechanism. J. Biomed. Biotechnol., 2012: 1-9.

Korashy HM, MA El Gendy, AA Alhaider and AO 1Kadi, 2012. Camel milk modulates the expression of aryl hydrocarbon receptor-regulated genes, Cyp1a1, Nqo1, and Gst1a2, in murine hepatoma hepa 1c1c7 cells. J. Biomed. Biotechnol., 2012: 1-10.

Lauwereys M, A Ghahroudi and A Desmyter, 1998. Potent enzyme inhibitors derived from dromedary heavychain antibodies. EMBO. J., 17: 3512-3120.

Muyldermans S, T Atarhouch and J Saldanha, 1994. Sequence and structure of VH domain from naturally occurring camel heavy chain immunoglobulins lacking light chains. Protein. Eng., 7: 1129-1135.

Rood BR, TJ Macdonald and RJ Packer, 2004. Current treatment of medulloblastoma: recent advances and future challenges. Semin. Oncol., 31: 666-675.

Sidgi Hasson SA, JZ Al-Busaidi, AM Al-Qarni, RS Al-Bahlani, MA Idris and TA Sallam, 2015. In Vitro Apoptosis Triggering in the BT-474 Human Breast Cancer Cell Line by Lyophilised Camel's Milk. Asian Pac. J. Cancer Prev., 16: 6651-6661.

Vladimir NU, ME Esmail, MA Marwa, AA Hussein and MR Elrashdy, 2017. Divergent anticancer activity of free and formulated camel milk $\alpha$-lactalbumin. Cancer. Invest., 35: 610-623.

Van Boekel MA, CN Weerens, A Holstra, CA Scheidtweiler and GM Alink, 1993. Antimutagenic effects of casein and its digestion products. Food. Chem. Toxicol., 31: 731-737.

Yagil R, 1982. Camels and camel milk (FAO Animal production and health paper 26). Food and Agriculture Organization of the United Nations, Rome, Italy.

Zarogoulidis P, K Tsakiridis, C Karapantzou, S Lampaki, I Kioumis, G Pitsiou, A Papaiwannou, W HohenforstSchmidt, H Huang, G Kesisis, I Karapantzos, S Chlapoutakis, I Korantzis, A Mpakas, V Karavasilis, I Mpoukovinas, Q Li and $\mathrm{K}$ Zarogoulidis, 2015. Use of proteins as biomarkers and their role in carcinogenesis. J. Cancer., 6: 9-18. 